This item was submitted to Loughborough's Research Repository by the author.

Items in Figshare are protected by copyright, with all rights reserved, unless otherwise indicated.

\title{
Fuel price differentials and car ownership: A spatial analysis of diesel cars in Northern Ireland
}

PLEASE CITE THE PUBLISHED VERSION

https://doi.org/10.1016/j.trd.2018.07.008

PUBLISHER

(C) Elsevier

VERSION

AM (Accepted Manuscript)

\section{PUBLISHER STATEMENT}

This work is made available according to the conditions of the Creative Commons Attribution-NonCommercialNoDerivatives 4.0 International (CC BY-NC-ND 4.0) licence. Full details of this licence are available at: https://creativecommons.org/licenses/by-nc-nd/4.0/

\section{LICENCE}

CC BY-NC-ND 4.0

\section{REPOSITORY RECORD}

Morton, Craig, Robin Lovelace, Ian Philips, and Jillian Anable. 2019. "Fuel Price Differentials and Car Ownership: A Spatial Analysis of Diesel Cars in Northern Ireland”. figshare. https://hdl.handle.net/2134/34103. 


\title{
Fuel Price Differentials and Car Ownership: A spatial analysis of diesel cars in Northern Ireland
}

\author{
Craig Morton ${ }^{A^{*}}$ \\ Robin Lovelace ${ }^{B}$ \\ Ian Philips ${ }^{B}$ \\ Jillian Anable ${ }^{B}$ \\ A School of Architecture, Building, and Civil Engineering, Loughborough University, Loughborough, \\ LE11 3TU, United Kingdom \\ ${ }^{B}$ Institute for Transport Studies, University of Leeds, Leeds, LS2 9JT, United Kingdom \\ *: correspondence author- c.morton@live.co.uk
}

\begin{abstract}
Car fleets across much of Europe have undergone a process of dieselisation over the past 20 years. Understanding the factors driving this process is therefore important for sustainable transport policy, with implications for how governments steer their national car fleets towards ultra-low emission vehicles in the future. At a general level, this paper contributes to this wider body of work which aims to understand the factors which led to the transition from petrol to diesel. Specifically, the paper investigates whether the availability of relatively cheap diesel fuel in the Republic of Ireland affected the rate of diesel car ownership in Northern Ireland. A geographic approach is used, which involves generating spatial variables measuring nearness to the Republic of Ireland and comparing these with the proportion of the local car stock that is fuelled by diesel. A series of spatial regression models are specified to determine if this association between nearness to the Republic and diesel ownership persists after accounting for the effect of socioeconomic, travel, and household characteristics. The results support the hypothesis that the availability of cheaper fuel in the Republic of Ireland is not only generating fuel-tourism, but is also affecting the structure of the car fleet registered in Northern Ireland. The findings are relevant beyond the case study and imply that the structure of a country's car fleet is not only dependent on domestic policies, but is also affected by the policies of neighbouring countries.
\end{abstract}

\section{Keywords}

Diesel, car ownership, vehicle stock model, fuel tourism, spatial arbitrage.

\section{Highlights}

- Northern Ireland has a distinctly high rate of diesel car ownership

- The Republic of Ireland has historically had cheaper diesel fuel prices

- Nearness to the border is linked with higher diesel car ownership

- $4 \%$ of diesel car ownership in the North is linked to cheaper fuel availability

\section{Citation}

Morton, C., Lovelace, R., Philips, I., \& Anable, J. (2018). Fuel price differentials and car ownership: A spatial analysis of diesel cars in Northern Ireland. Transportation Research Part D: Transport and Environment, 63, 755-768. https://doi.org/10.1016/j.trd.2018.07.008 


\section{Introduction}

Since the end of the twentieth century, the European car fleet has undergone a process of dieselisation, whereby diesel engines have progressed from existing in a market niche to having parity with petrol engines (Schipper and Fulton, 2013). This transition was motivated by a host of factors including the ability of diesel engines to offer reduced carbon dioxide emission factors and increased fuel economy compared to petrol engines as well as a desire to establish a larger market for diesel fuels. Recently, the popularity of diesel engines has come under scrutiny, due in part to increased concerns regarding air quality levels and the disparity between official emission factors for local air pollutants generated by diesel engines and those observed during real-world driving conditions (Brand, 2016). This situation has led to certain urban areas proposing bans on the use of diesel cars and calls for a shift away from diesel engines throughout the car fleet.

Such a shift could be facilitated by a set of government policies which push drivers away from diesel cars (e.g. the introduction of Clean Air Zones and surcharges on diesel fuel tax) and pull drivers towards low emission vehicles (e.g. vehicle scrappage schemes and purchase incentives) (Brand et al. 2013). The efficacy of such a strategy is contingent on the ability of the government to exert control over the structure of the car stock. However, there are situations where the sovereignty of this control is diminished due to the policies being deployed by exogenous agents that also affect the structure of the car stock. A version of such a situation is where the domestic policy of one country extends into another, which may generate effects that are not aligned to the priorities of the host country.

This paper presents a case study of such a situation by examining how fiscal measures enacted in the Republic of Ireland may have affected the structure of the car fleet in Northern Ireland. Historically, the fuel tax on road diesel in the Republic has been lower than that in effect in Northern Ireland, which has led to diesel in the Republic having been as much as 30 pence (0.3 GBP) per litre cheaper since 2000. This price differential represents a spatial arbitrage opportunity, where drivers in one area (i.e. Northern Ireland) can derive an advantage (i.e. lowering their costs) from purchasing diesel in a nearby area (i.e. the Republic). The occurrence of fuel tourism across the Irish border is a known issue (Dineen et al. 2014; Kennedy et al. 2017), with $22.8 \%$ of the diesel fuel sold in the Republic estimated as being consumed in Northern Ireland. However, no work to date has examined if this availability of cheaper diesel across the border has motivated the purchase of diesel cars in Northern Ireland. This research aims to address this gap, by examining the geographical variation in diesel car ownership across Northern Ireland. The specific hypothesis examined in this research is that the effect of this price differential in diesel fuel on the registration of diesel cars diminishes as distance to the Republic increases (i.e. a distance decay effect).

\section{Background}

\subsection{Spatial Arbitrage}

Countries often employ fiscal measures to manage the demand for a good and raise tax revenue from its sale. In certain situations, neighbouring countries may follow different fiscal strategies, which leads to disparities in the sale price faced by consumers in the different countries. If the good in question is homogenous (i.e. its qualities do not differ between countries), this could generate a spatial arbitrage opportunity. Under such an opportunity, consumers of a good in a country which has a higher sales price may reduce the costs they face by travelling to the neighbouring country where the sales price is lower to make their purchase. Spatial arbitrage opportunities have been extensively evaluated for such goods as tobacco and alcohol (Leal et al. 2010). The phenomenon also extends to the transport sector, where the price of fuel faced by both private and freight consumers (Transport and Environment, 2011) in neighbouring countries or regions can be sufficiently different to induce what is often referred to as fuel-tourism behaviour (Rietveld et al. 2001; Banfi et al. 2005; Rietveld et al. 2005; Leal et al. 2009; Romero-Jordán et al. 2013). Such behaviour can generate several adverse 
consequences, such as reductions in tax and fuel station revenue in the country with the higher price level as well as increasing car travel. To date, no research has considered whether the occurrence of fuel tourism also affects the structure of the car fleet. The study presented in this paper addresses this gap and is likely to be of international relevance given the common occurrence of fuel price differentials amongst neighbouring countries.

\subsection{Dieselisation}

The share of diesel cars in new registrations across the European Union (EU) increased from $23.5 \%$ in 1995 to 55.7\% in 2011 (Association des Constructeurs Européens d'Automobiles, 2017). A similar, albeit delayed, trend was also observed in the United Kingdom (UK), where diesel cars represented less than $20 \%$ of new registrations in 2001 , with the market expanding to over $50 \%$ of new registrations in 2012 (Figure 1).

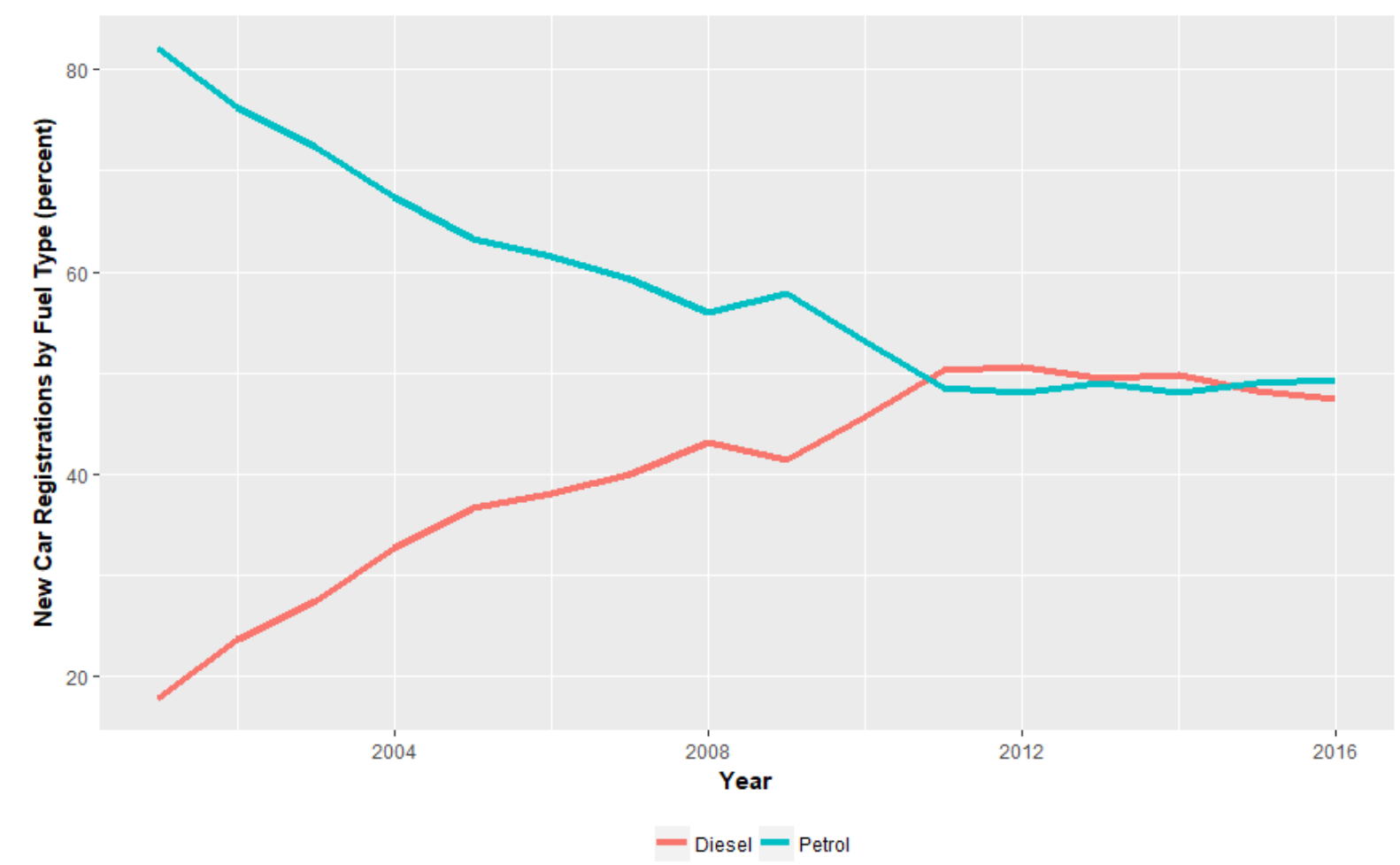

Figure 1: Proportion of new car registrations by fuel type in the United Kingdom (Department for Transport, 2016)

A combination of factors, linked to improvements in the technical performance of diesel engines and preferential taxation regimes for diesel fuel, contributed to this shift in car fuel type (Schipper et al. 2002; Mazzi and Dowlatabadi; 2007; Kågeson, 2013). Expectations were that increased penetration of these more technically efficient diesel cars into national fleets would have benefits for energy security and climate change mitigation (Bonilla 2009; Tovar, 2011). However, these expected benefits have been eroded by increases to diesel car horsepower and mass (Zachariadis, 2013; Schipper and Fulton, 2009; Schipper and Fulton, 2013), confounded by diesel cars continuing to be driven more than petrol cars (Schipper and Fulton, 2013) and an increasing gap between official emission factors and those observed during real-world driving conditions (Carslaw et al. 2011; Moody and Tate, 2017). The shift towards diesel cars has simultaneously led to expansions in the quantity of local pollutants (e.g. particulate matter and nitrogen oxides) emitted from car use (Mazzi and Dowlatabadi, 2007), with the UK's Royal College of Physicians (2016) estimating that 40,000 deaths per year can be attributed to the inhalation of these compounds. 
Due to these implications, the anticipated benefits of the shift to diesel have generally failed to materialise, which raises questions about what value if any the process of dieselisation has generated. Through an integrated simulation model of the UK transport system, Brand (2016) illustrates how the introduction of a purchase tax on new diesel cars alongside a widespread commitment to supporting Electric Vehicles could reverse this process and promote a shift to a low-emission fleet. However, the effectiveness of these measures relies on the government having control over the factors which effect fleet composition. The case study presented in this paper demonstrates that such control may be diluted by policies enacted in neighbouring jurisdictions.

\subsection{The Situation in Northern Ireland}

Northern Ireland represents the only nation of the UK that has a land border with another country, being the Republic of Ireland to the south and west. At the time of writing, fuel duty in Northern Ireland is 57.95 pence per litre for diesel plus a $20 \%$ value added tax to the sale price. In the Republic the fiscal measures differ, with fuel duty for diesel set at 42.57 cent per litre, a carbon tax of 5.33 cent per litre, and a $23 \%$ value added tax on the sale price.

Due to the divergent fiscal measures in effect between Northern Ireland and the Republic, a substantial price difference 'at the pump' is apparent. Figure 2 displays the average diesel fuel price between 2000 and 2016 for Northern Ireland and the Republic, with the price difference persevering throughout this period. At its most divergent (in 2002), the differential in fuel price between the two countries was 31 pence per litre, with an average difference of 20 pence per litre. In part, the fluctuation in the difference in diesel price between Northern Ireland and the Republic is also motivated by changes in the currency exchange rate. Indeed, the narrowing of the gap between 200709 corresponds to a substantial devaluation of the British pound against the Euro.

Research commissioned by the National Roads Authority (2013) in the Republic provides insights on the magnitude of the fuel tourism occurring across the Irish border. Through an inspection of vehicle specific fuel consumption and the quantity of fuel sold in the two jurisdictions, the research estimates that 426,800 tonnes of diesel sold in the Republic were consumed in Northern Ireland in 2000, increasing to 494,000 tonnes in 2011 . This equates to $22.8 \%$ of all diesel sales in the Republic being linked to fuel tourism in 2011. In terms of the economic impact of this issue, Kennedy et al. (2017) estimated that in $\mathbf{2 0 1 5}$ over $€ 202$ million of diesel sales in the Republic can be attributed to fuel tourism from Northern Ireland. Due to the persistence of this price differential, the possibility exists for it not only to have generated fuel-tourism but to also have motivated a higher rate of diesel car ownership in Northern Ireland due to the availability of cheaper fuel across the border. 


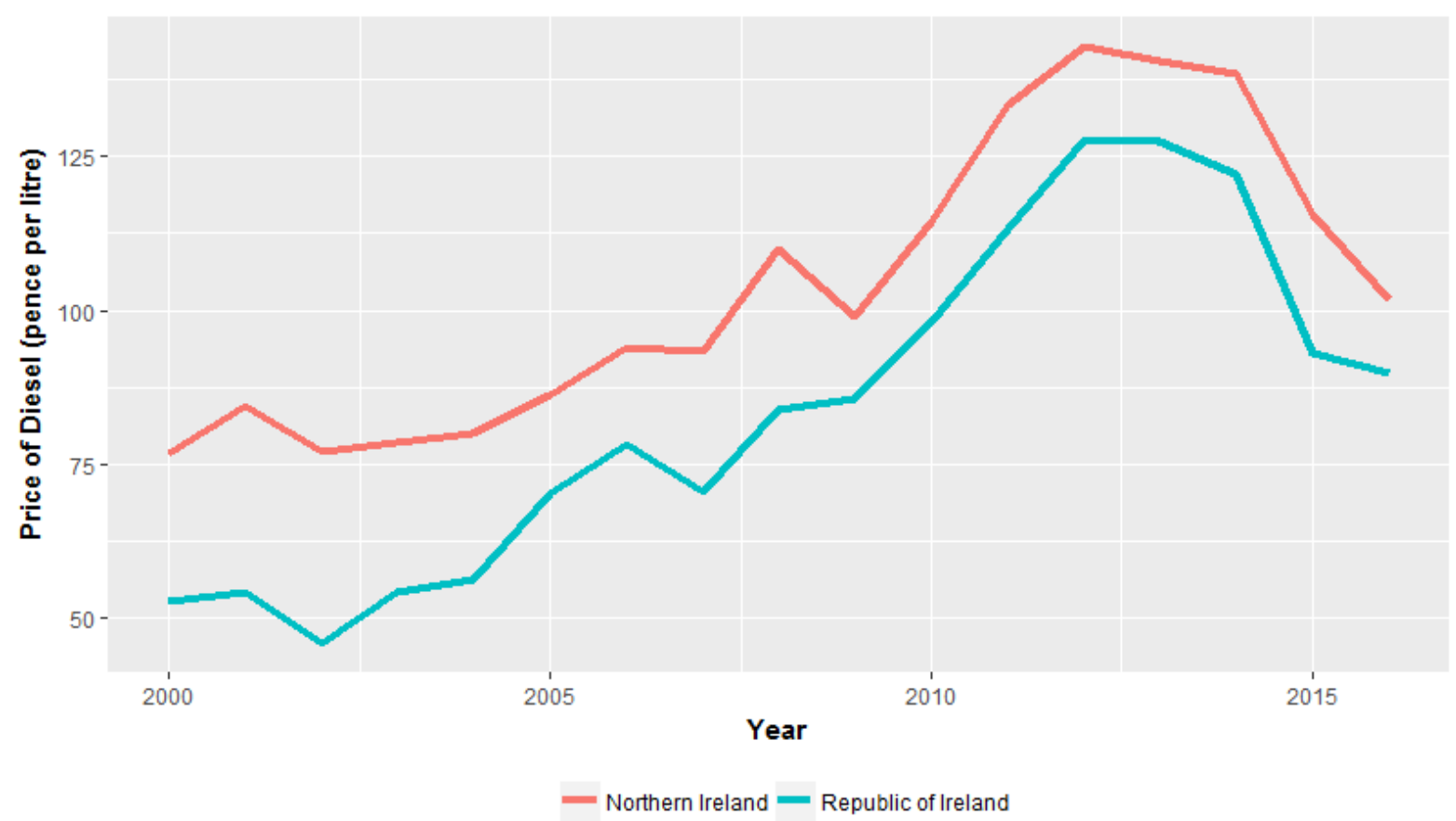

Figure 2: Average price of diesel road transport fuel in Northern Ireland and the Republic of Ireland (Automobile Association, 2017)

In parallel to the fuel price difference between Northern Ireland and the Republic, another set of issues are at play that could affect the rate of diesel car ownership. The smuggling of cheaper fuel from the Republic into Northern Ireland by organised crime is a known issue (House of Commons, 2012). In addition, fuel laundering operations, which take rebated diesel (i.e. diesel sold for use off-road and not subjected to fuel duty, referred to as 'red diesel' in the UK) and remove the marker dyes, have a relatively high occurrence in Northern Ireland. These two issues lead to a situation whereby around $12 \%$ of the diesel sold for road transport in Northern Ireland is estimated to be illicit (House of Commons, ibid.). It is plausible that these two issues will be concentrated in the border region due to the proximity to cheaper fuel and the relatively high level of rurality.

\subsection{Car Fleet Composition}

The structure of a local car fleet is likely to be contingent on situational factors that make the ownership and use of certain types of car more or less suitable. These situational factors cover such issues as the socioeconomic characteristics of the resident population, the features of the transport system, and the presence of policies designed to promote or hinder particular car types.

Within the UK, the rate of car ownership and how this rate changes both spatially and temporally has been examined (Clark, 2007; Clark and Finley, 2010; Clark and Rey, 2017). Evidence is also present for geographical variation in the different types of car that are owned. Adjemian et al. (2010) examined the occurrence of car body types across census tracts of California and found that such factors as income level, education level, age profile, ethnic makeup, and the marital status of the population are useful in explaining the presence of certain car variations. This study also found ownership of some vehicle types to be spatially dependent, whereby the rate in one area tends to be related to the rates displayed in neighbouring areas. Chatterton et al. (2015) and Cairns et al. (2017) used UK vehicle stock, vehicle inspection test (providing Odometer readings), and Census data to examine the spatial variation in key vehicle parameters. Similarly, recent examination of car body type across the neighbourhoods of the UK found that certain types of vehicle are related to particular socioeconomic classes, such as the rate of luxury car ownership being associated with the rate of the population in managerial or professional employment (Lansley, 2016). 
The prevalence of different powertrains within local fleets has also been investigated to determine what conditions are linked to registrations of alternatively fuelled cars. The rate of Hybrid Electric Vehicles (HEVs) has been found to be associated with the education and income levels of the population as well as car availability levels, commuting distances, and household size (Dimatulac and Maoh, 2017; Liu et al. 2017). In terms of the presence of local supporting policies, the exemption of HEVs from the London Congestion Charge has been identified as a salient issue in consumer's decisions to purchase a HEV (Ozaki and Sevastyanova, 2011), with Morton et al. (2017) finding that the rate of HEV ownership tends to increase as the rate of commuting by car to the London Congestion Charge zone increases. Similar evaluations have been conducted on the exemption of natural gas vehicles from the Stockholm Congestion Charge, with this policy estimated to have increased registrations of natural gas vehicles between 1.2\% (Mannberg et al. 2014) and 1.8\% (Whitehead et al. 2014). These studies endorse the view that nearness to a policy which benefits one particular car variant (such as a certain powertrain) can encourage the registrations of such vehicles in the surrounding areas. The research reported in this paper examines if such an effect is present in terms of fuel tourism between Northern Ireland and the Republic by evaluating whether the availability of cheaper diesel fuel in the Republic is promoting registrations of diesel cars in Northern Ireland.

\section{Methods}

\subsection{Sources of Data}

The dataset analysed in this paper has been assembled from two public records. First, the Department for Transport's (2016) Vehicle Licensing Database represents the source of the vehicle stock data, noting the number of cars registered to private households across Northern Ireland by fuel type. The number of cars registered to corporations has been excluded from the assessment, thus the presence of company fleets and any associated differences in responsiveness to fuel price differentials should not unduly distort the results of the analysis. Second, the Northern Ireland Population Census (Northern Ireland Statistics and Research Agency, 2011) represents the source of the socioeconomic, household, and transport system data. The variables incorporated into the dataset are described in Table 1 and are contrasted with those for the rest of the United Kingdom (i.e. Great Britain).

Table 1: Descriptive statistics of the dataset used in the analysis and comparison to Great Britain

\begin{tabular}{lrrrr}
\hline & \multicolumn{2}{c}{ Northern Ireland } & \multicolumn{2}{c}{ Great Britain } \\
\cline { 2 - 5 } & \multicolumn{1}{c}{ Mean } & Std. Dev. & Mean & Std. Dev. \\
\hline Variable of Interest & & & & \\
Diesel Cars (\%) & 49.927 & 15.619 & 35.452 & 5.740 \\
$\quad$ Socioeconomics & & & & \\
Mean Age (years) & 37.836 & 3.901 & 39.700 & 3.102 \\
Self Employed (\%) & 8.587 & 4.319 & 9.496 & 2.846 \\
University Degree (\%) & 23.336 & 9.643 & 26.747 & 8.318 \\
$\quad$ Travel & & & & \\
One Car Household (\%) & 41.344 & 6.380 & 42.262 & 2.985 \\
Car Driver to Work (\%) & 56.131 & 10.766 & 60.016 & 12.846 \\
Over 30 km to Work (\%) & 8.284 & 5.948 & 7.994 & 3.939 \\
$\quad$ Household & & & & \\
Population Density (per hectare) & 21.397 & 24.572 & 20.223 & 25.655 \\
Mean Household Residents & 2.559 & 0.325 & 2.341 & 0.153 \\
Rent Household Socially (\%) & 14.652 & 14.324 & 17.978 & 7.795 \\
Flats (\%) & 8.335 & 9.806 & 21.050 & 16.594 \\
\hline
\end{tabular}




\subsection{Spatial Resolution}

The variables incorporated in the dataset have been aggregated at the Super Output Area (SOA) level of administrative geography. This covers 890 contiguous spatial units which contain a mean of 2,000 residents.

\subsection{Measurement of Nearness}

Estimating how close a spatial unit is to the Republic represents an issue of central importance as it acts as a proxy of nearness to cheaper diesel fuel. A set of different methods have been followed to approach the issue. Each of the methods is employed in the analysis to consider if the association between nearness to the Republic and the ownership of diesel cars persists across different measurement procedures.

\subsubsection{Contiguity Method}

A set of distance based buffers from the border with the Republic are set. These buffers group spatial units that intersect a 5 kilometre $(n=104), 10$ kilometre $(n=45), 15$ kilometre $(n=31)$, and 20 kilometre $(n=36)$ buffer to the border as well as those which comprise the remainder of Northern Ireland $(n=674)$. This arrangement is illustrated in Figure 3a. The hypothesis here is that spatial units that have closer contiguity to the border with the Republic will tend to have higher rates of diesel car ownership.

\subsubsection{Proximity Method}

The centroid of each spatial unit is extracted and the position of each road crossing between Northern Ireland and the Republic is mapped. The Euclidean distance (i.e. straight-line distance) in kilometres between each centroid and the closest road crossing is calculated. The hypothesis here is that as the Euclidean distance to the closest road crossing increases, the rate of diesel car ownership will tend to decrease.

\subsubsection{Network Distance Method}

The centroid of each spatial unit is extracted and the location of the closest fuel station in the Republic is mapped. The road network distance in kilometres between each centroid and the closest fuel station in the Republic is calculated. This arrangement is illustrated in Figure $3 \mathrm{~b}$. The hypothesis here is that as network distance to the closest fuel station increases, the rate of diesel car ownership will tend to decrease.

\subsubsection{Network Time Method}

The centroid of each spatial unit is extracted and the location of the closest fuel station in the Republic is mapped. The road network time to travel by car in minutes between each centroid and the closest fuel station in the Republic is estimated. The hypothesis here is that as network time to the closest fuel station increases, the rate of diesel car ownership will tend to decrease. For both the network distance and network time methods, the routing algorithm produced by the GraphHopper service and implemented in the R package stplanr (R Core Team 2017; Lovelace and Ellison under review) was used to determine shortest paths. 

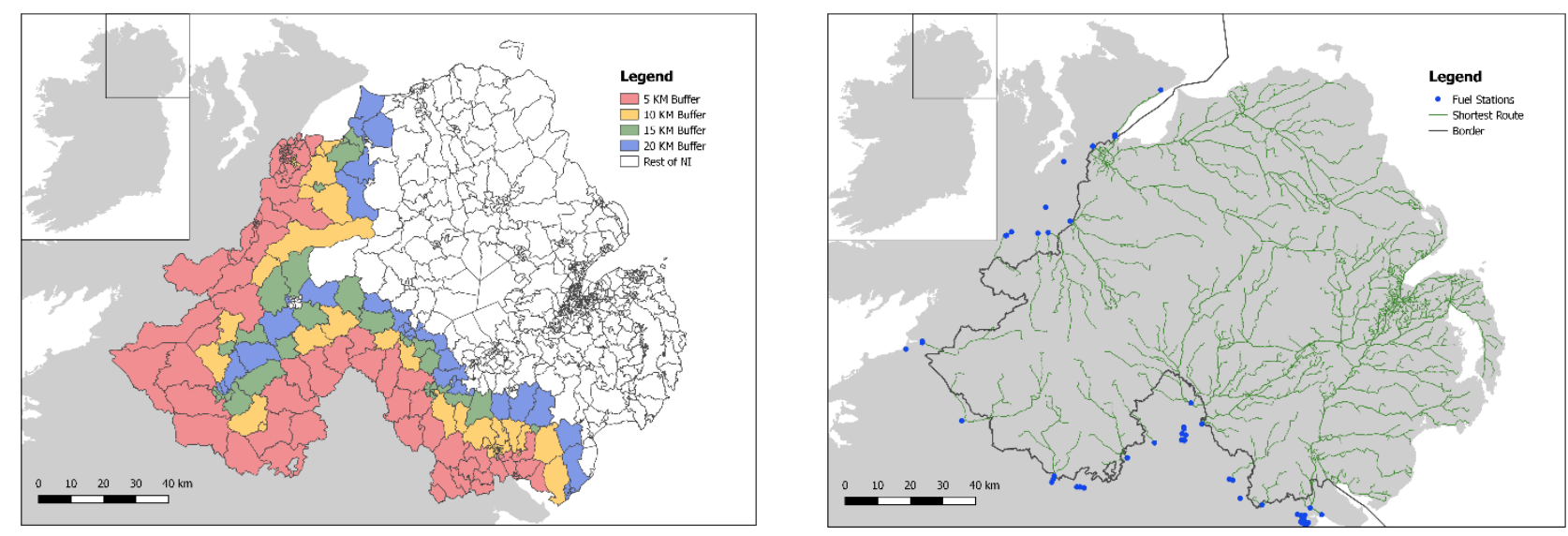

Figure 3: Maps illustrating the (a) Super Output Areas that intersect set buffers to the border with the Republic of Ireland and (b) the network distance from the Super Output Areas to fuel stations in the Republic of Ireland

\subsection{Statistical Analysis}

The assessment of the dataset progresses through a series of stages.

\subsubsection{Stage One}

First, the spatial variation in diesel car ownership is considered. A boxplot (Figure 4) is produced that displays the proportion of the private local authority car fleet that is fuelled by diesel grouped across the Government Office Regions of the UK. A choropleth map (Figure 5) using equal bin counts and depicting the rate of private diesel car ownership across the SOAs of Northern Ireland is produced. The degree to which the rate of diesel car ownership in Northern Ireland displays spatial dependence (i.e. non-random spatial patterning) is evaluated through a spatial autocorrelation analysis. A spatial weights matrix, which allows for the calculation of spatial lags of variables, is specified following a binary queen contiguity approach whereby spatial units are classified as neighbours if they share a line or a point border. This matrix is summarised in Equation 1 where Wij is the contiguity between spatial units $i$ and $j$. The global spatial autocorrelation Moran's-I statistic (Moran, 1948) is calculated to consider the degree to which the rate of diesel ownership is correlated between neighbouring spatial units. The Local Indicator of Spatial Association (LISA; Anselin, 1995) is also calculated (Figure 6) to assess if particular regions are exhibiting similar rates of diesel car ownership, indicating the presence of hot-spots and cold-spots.

$$
\begin{aligned}
& W=\left|\begin{array}{ccc}
W_{11} & \cdots & W_{n 1} \\
\cdots & & \\
& W_{i j} & \\
W_{1 n} & & W_{n n}
\end{array}\right| \\
& W_{i j}=\left\{\begin{array}{l}
1 \quad \text { if spatial unit } j \text { and } i \text { are neighbours } \\
0 \text { if spatial unit } j \text { and } i \text { are not neighbours }
\end{array}\right.
\end{aligned}
$$

\subsubsection{Stage Two}

Second, the association between nearness to the Republic and the proportion of the private local car stock that is diesel fuelled is evaluated. A boxplot (Figure 7) of the rate of diesel car ownership across the SOAs grouped by buffer category (i.e. the contiguity method) is produced. The Kruskal-Wallis test is applied to determine if these groups of SOAs significantly differ in terms of their rate of diesel car ownership. A set of scatterplots (Figure 8) are produced which have the rate of diesel car ownership across the SOAs on the $y$-axis and Euclidean distance to the closest road crossing (i.e. the proximity 
method), network distance to the closest fuel station in the Republic (i.e. the network distance method), and network time to the closest fuel station (i.e. the network time method) on the x-axis. A Spearman's correlation analysis is utilised to determine if these variables are significantly related to one another.

\subsubsection{Stage Three}

Third, log-log regression models ${ }^{1}$ are specified to explain variation in private diesel car ownership across the SOAs. A set of socioeconomic, household, and transport system area characteristics are included in the analysis as independent variables to control for the ancillary factors which may affect the rate of diesel car ownership. To begin, a series of five benchmark OLS models are produced (Table 2) which iteratively introduce the measurements of nearness to the Republic to examine whether the availability of cheaper diesel fuel represents a significant issue.

To determine if the benchmark OLS models need to be extended through the integration of spatial interaction effects to account for persisting spatial autocorrelation, the robust Lagrange Multiplier diagnostics are calculated (Anselin et al. 1996). Following this, the extension of the benchmark OLS to cover the occurrence of local spatial spillovers is conducted through the specification of the Spatial Durbin Error Model (SDEM; Table 3; LeSage and Pace, 2009; Elhorst, 2014) through the SPDEP package built in the R statistical programming language (Bivand et al. 2011). The SDEM incorporates spatial lags of the model independent variables to allow for direct, indirect, and total effects to be estimated. The model also contains a spatial lag of the benchmark OLS model's residual to account for spatial dependence in the variables omitted from the analysis. Equation 2 and 3 summarise the structure of the SDEM.

$$
\begin{gathered}
y=\alpha+\beta_{a} x_{a}+\beta_{d} x_{d}+\theta W X+u \\
u=\lambda W u+\varepsilon
\end{gathered}
$$

Where:

$y$ is a vector of observations of diesel car ownership

$\alpha$ is a constant parameter

$B_{a}$ is a vector of coefficients associated with the area characteristics

$x_{a}$ is a vector set of observations of the area characteristics

$B_{d}$ is a coefficient associated with the network distance variable

$x_{d}$ is a vector of observations of the network distance variable

$\theta$ is a vector of coefficients associated with the spatially lagged independent variables

$W X$ is a vector set of observations of spatially lagged independent variables

$\lambda$ is a coefficient associated with the spatially lagged OLS residual

$W u$ is a vector of observations of the spatially lagged OLS residual

$\varepsilon$ is the model residual

\subsection{Limitations}

The research reported in this paper is limited by a number of factors that should be considered when interpreting the findings. First, it is questionable whether the measurements of nearness to the border described in Section 3.3 fully capture the occurrence of fuel tourism. A more robust approach could use a measurement of interaction with the Republic, such as the number of individuals commuting by car into the Republic from each spatial unit. The Northern Ireland Statistics and Research Agency were approached for such data but the request was declined.

\footnotetext{
${ }^{1}$ For two independent variables measuring percentage of the housing stock that is [1] flats and [2] socially rented, one spatial unit in each instance has a zero observation. To allow for the calculation of natural logarithms, a small constant (0.01) was added to these variables.
} 
Second, a degree of temporal divergence exists in the data utilised in the analysis. The variable of interest (percentage of local private car fleet which is fuelled by diesel) was recorded in 2016, while the independent variables (socioeconomic characteristics, household attributes, and transport features) were recorded in 2011. Thus, one of the underlining assumptions of the analysis is that no substantial changes in the composition of the spatial units have occurred in the intervening period.

Third, the analysis is based on aggregate data which restricts the inferences that can be made to individual actions from the results. Often referred to as the Ecological Fallacy problem (Harris et al. 2005), this limitation advises that micro level interpretations of macro level observations should be treated with caution.

\section{Results}

\subsection{Spatial Variation in Diesel Ownership}

Figure 4 displays the rate of diesel car ownership across the local authorities of the UK grouped by Government Office Region. From this figure, it is apparent that the local authorities of Northern Ireland tend to contain higher proportions of diesel cars in their fleets compared to other regions. This observation indicates that a factor is active in Northern Ireland that is encouraging the ownership of diesel cars which is not present in the rest of the UK.

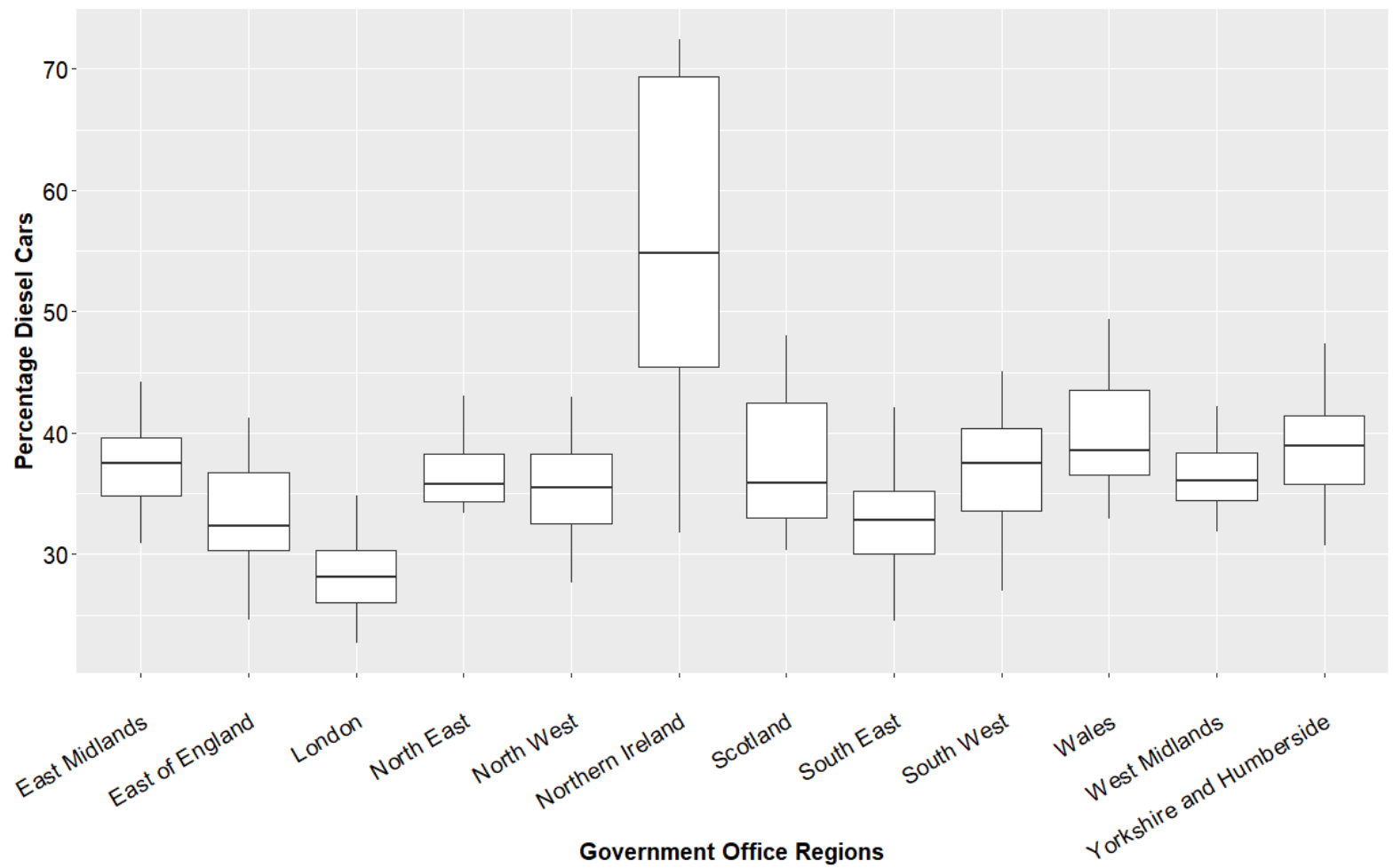

Figure 4: The percentage of private local car fleets that are fuelled by diesel grouped by Government Office Region

Examining the spatial variation in diesel car ownership that is present within Northern Ireland, Figure 5 illustrates the percentage of the private car fleet which is diesel fuelled across the SOAs. In this figure, it is evident that spatial units that are closer to the border with the Republic tend to display higher rates of diesel car ownership, with the rate diminishing as proximity to Belfast (the national capital located in the mid-east) increases. The border region is predominantly rural in nature, with much of the economic activity focused on agriculture, with these two issues likely being factors in the relatively high rates of diesel car ownership present in this area. 


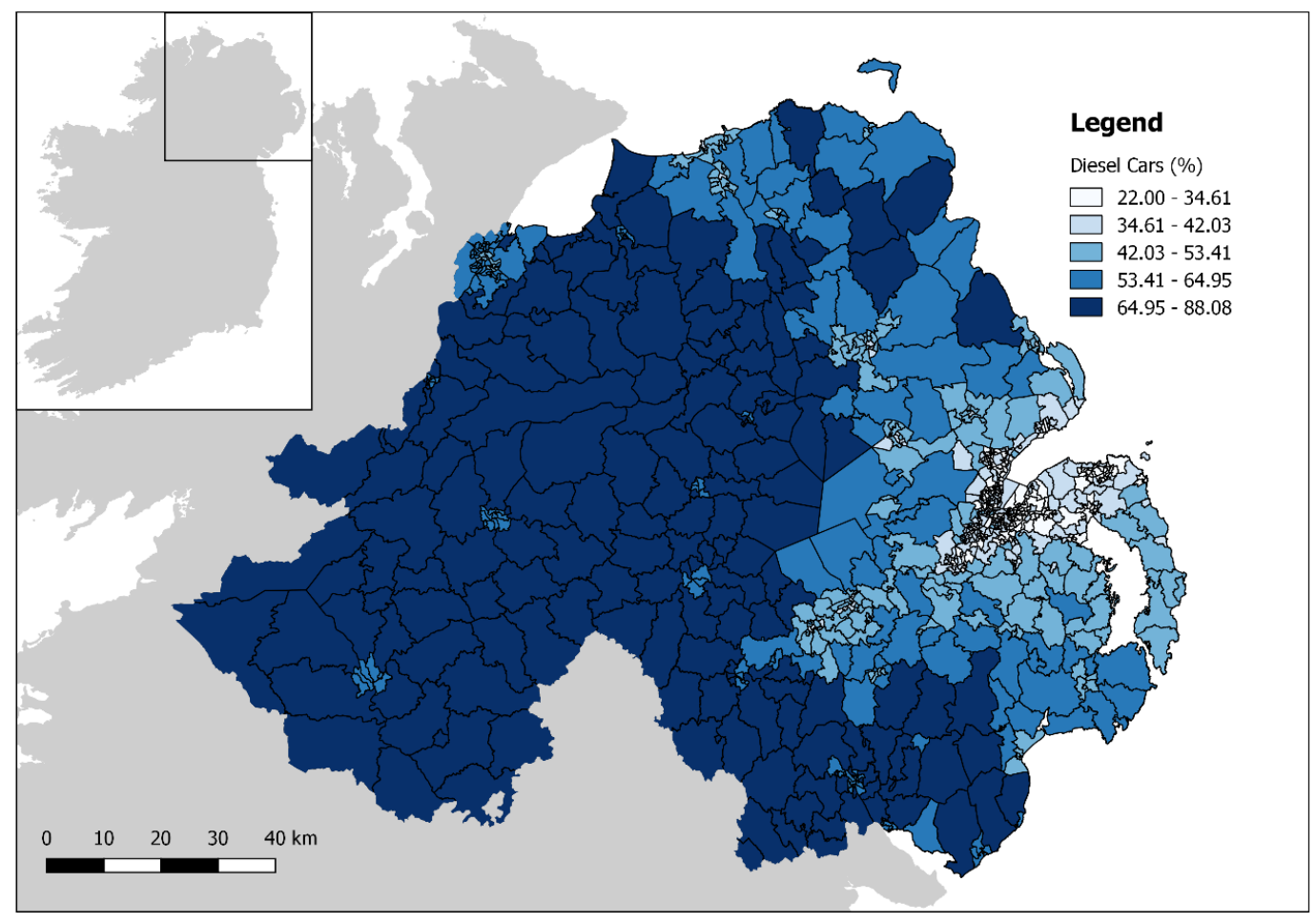

Figure 5: Choropleth map showing the proportion of the private local car fleet that is diesel fuelled across the Super Output Areas of Northern Ireland

The spatial patterning in the rate of diesel car ownership also exhibits signs of spatial dependence, whereby the proportion of the car fleet which is diesel fuelled in one spatial unit tends to be related to the proportion observed in neighbouring spatial units. This is supported by Moran's-I test of spatial autocorrelation, which returns a strong positive coefficient $(I=0.919, p$-value $<0.01)$. The occurrence of spatial dependence is clearly visible in the LISA analysis reported in Figure 6 . Here, it is apparent that the border region of Northern Ireland, and extending a considerable distance inland, represents a hot-spot of diesel car ownership (i.e. classified as high-high). This border region is predominately rural in terms of its settlement pattern, with the city of Londonderry (located at the North-West border to the Republic) being the only major urban centre. Conversely, a cold-spot (i.e. classified as low-low) is present in the mid-east of the country and corresponds with the metropolitan area of Belfast. A number of small regions which display no significant spatial autocorrelation appear to be sporadically distributed throughout the border hot-spot. These small non-significant regions correspond to the border towns (such as Omagh, Armagh, and Enniskillen), indicating that the well-known rural-urban divide is present in terms of diesel car ownership (airns et al. 2017). 


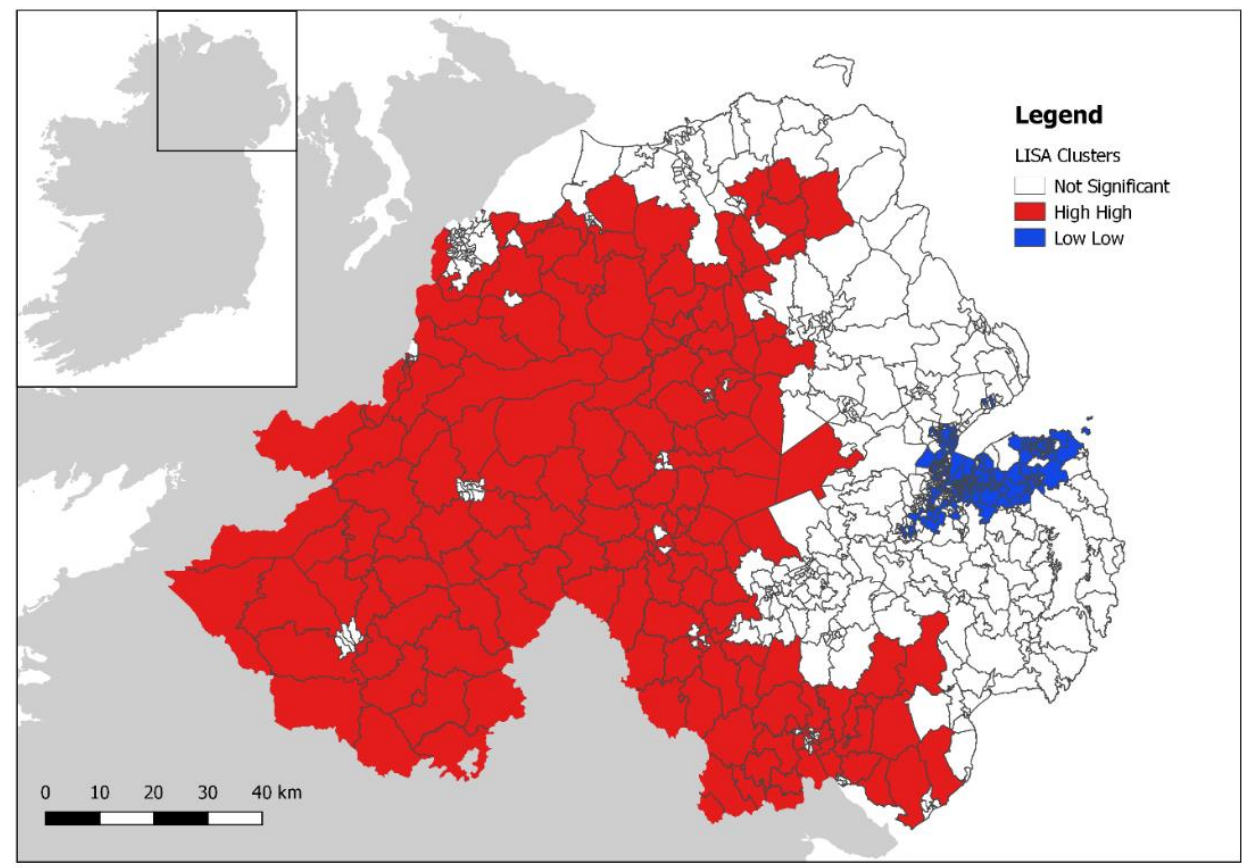

Figure 6: Local indicator of spatial association concerning the proportion of the private local car fleet which is diesel fuelled

\subsection{Nearness to the Republic of Ireland}

Figure 7 displays the dispersion of the private local car fleet that is fuelled by diesel across the border buffer groups of SOAs (i.e. the contiguity method). SOAs that intersect a 5, 10, 15, and $20 \mathrm{~km}$ buffer with the border to the Republic of Ireland appear to have similar rates of diesel car ownership. This rate decreases noticeably for the SOAs that are outside of a $20 \mathrm{~km}$ buffer to the border (i.e. the rest of Northern Ireland), where the average rate of private diesel car ownership is approximately $40 \%$. The visible difference between the SOAs of the rest of Northern Ireland category and those assigned to the buffer categories is supported by a significant Kruskal-Wallis test result $(\mathrm{H}=335.929, \mathrm{p}$-value < 0.01 ).

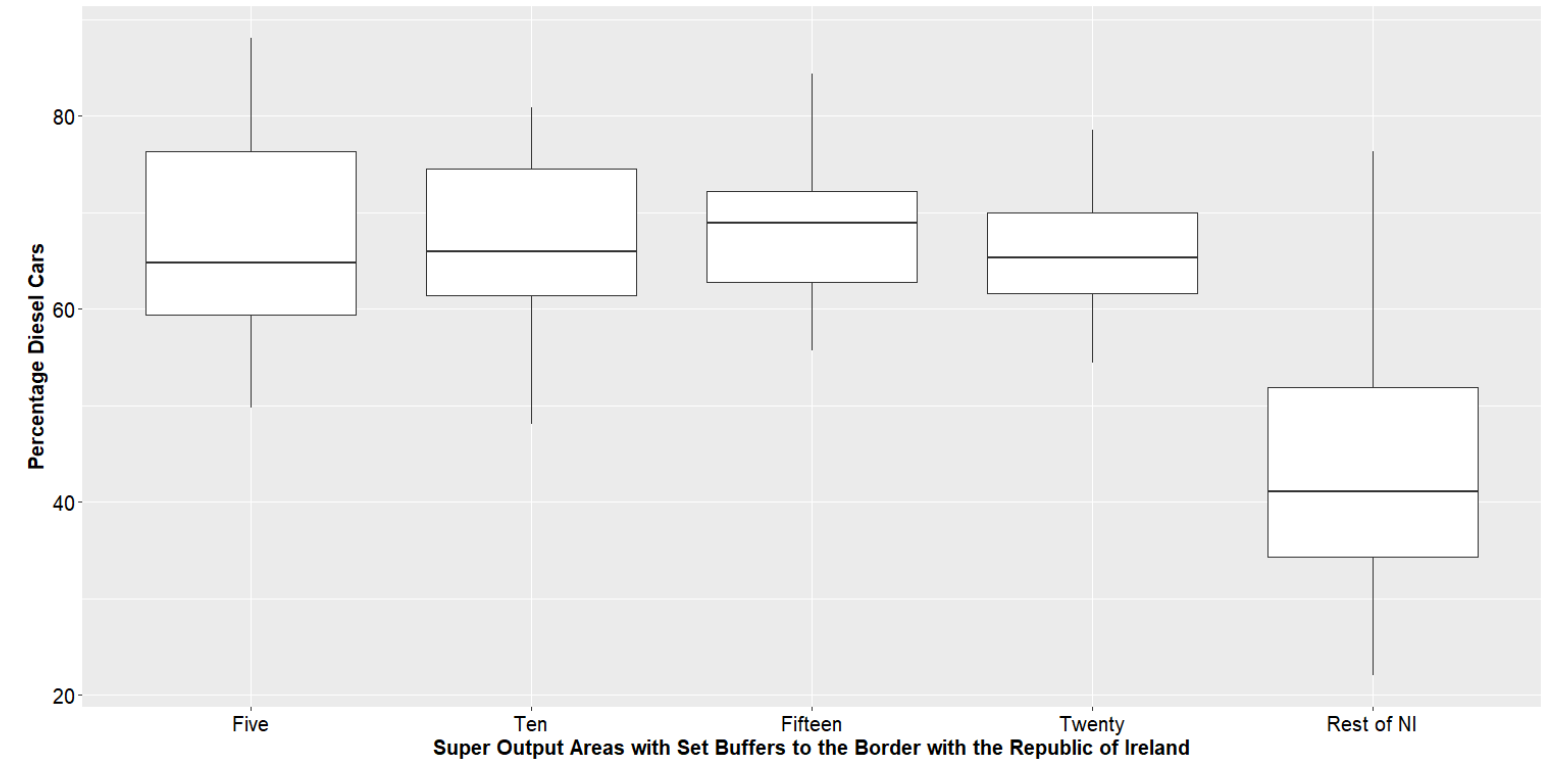

Figure 7: The percentage of private local car fleets that are fuelled by diesel grouped by buffer category to the Republic of Ireland 
Figure 8a evaluates the relationship between diesel car ownership and Euclidean distance to the nearest road crossing into the Republic (i.e. the proximity method). In this instance, a negative relationship is evident $\left(r_{s}:-0.713, p\right.$-value $\left.<0.01\right)$, implying that as proximity to the border decreases, the rate of diesel car ownership tends to decrease. A similar set of findings are observed when considering network distance to the nearest fuel station in the Republic (Figure 8b; $r_{s}:-0.598, p$-value $<0.01$ ) and network time to the nearest fuel station (Figure $8 c ; r_{s}:-0.475, p$-value $<0.01$ ).

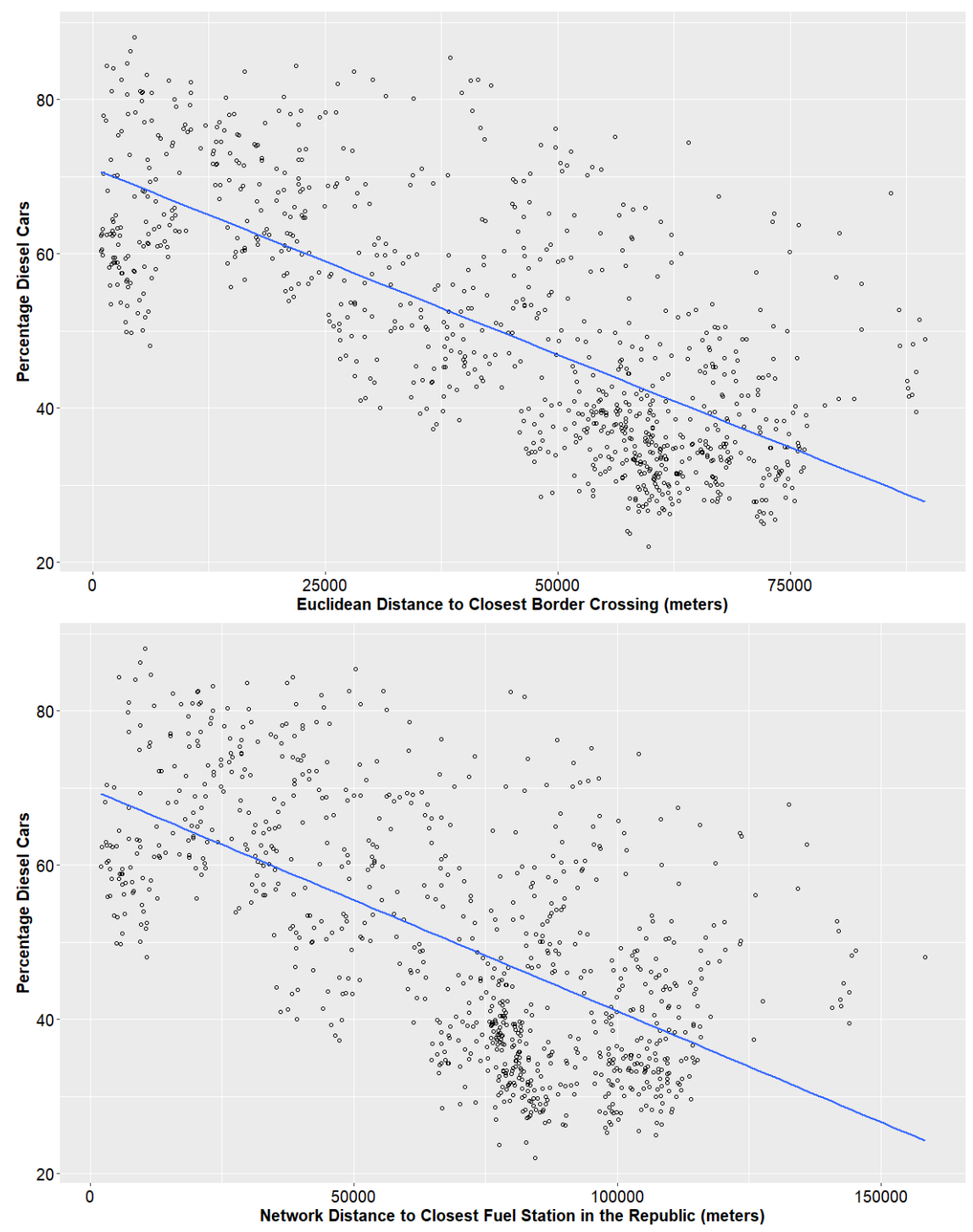




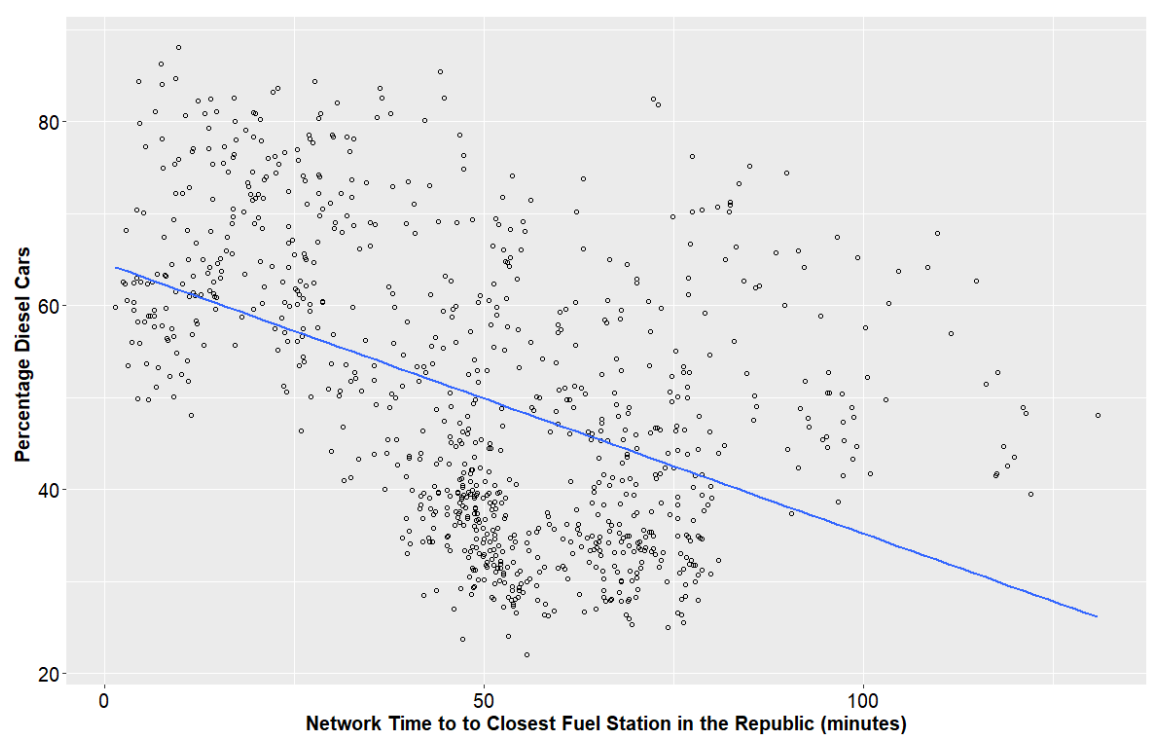

Figure 8: Scatterplots of the proportion of the Super Output Area private car fleet that is diesel fuelled (y-axis) against (a) Euclidean distance to the nearest road crossing to the Republic of Ireland, (b) network distance to the nearest fuel station in the Republic of Ireland, and (c) network time to the nearest fuel station in the Republic of Ireland

\subsection{Regression Analysis}

The benchmark log-log OLS regression models, which have the proportion of the private car stock which is diesel fuelled as the dependent variable, are reported in Table 2. The highest Variance Inflation Factor (VIF) observed across the models is 7.66, with a mean VIF of 3.29, indicating that the models are not unduly biased by multicollinearity. The base model (OLS Model 1 ) which includes socioeconomic, travel, and household characteristics, is capable of accounting for $78 \%$ of the variance in the rate of private diesel car ownership. The inclusion of measurements of nearness to the Republic (OLS Models 2 to 5) provide significant improvements to model fit.

The dummy variables which cover $5 \mathrm{~km}$ (Beta: 0.241), 10km (Beta: 0.232), 15km (Beta: 0.231), and $20 \mathrm{~km}$ (Beta: 0.163) buffers from the border all display significant coefficients, with the size of these coefficients diminishing as the contiguity to the Republic decreases. Moreover, the variables measuring the Euclidean distance to the nearest road crossing (Beta: -0.107), the network distance to the nearest fuel station (Beta: -0.128 ), and the network time to the nearest fuel station (Beta: -0.135 ) all hold significant negative coefficients. These findings indicate that there is a persisting association between the proportion of the private car fleet that is diesel fuelled and nearness to the Republic, having controlled for the effects of socioeconomic, travel, and household characteristics.

Examining the spatial diagnostics which are reported at the bottom of Table 2, the robust Lagrange Multiplier (LM) tests return significant results in all instances and indicate that an extension of the benchmark OLS which corrects for persisting spatial autocorrelation in the model error term (i.e. the SDEM) is appropriate. As the model which incorporates the measurement of network distance to the nearest fuel station in the Republic (i.e. OLS: Model 4) displays the best model fit statistics, it is selected for extension. 
Table 2: Results of the benchmark log-log OLS regression models with the proportion of the private car fleet that is diesel fuelled as the dependent variable $(n=890)$

\begin{tabular}{|c|c|c|c|c|c|}
\hline & $\begin{array}{c}\text { OLS: M1 } \\
\text { Beta } \\
\text { (Std. Err.) }\end{array}$ & $\begin{array}{c}\text { OLS: M2 } \\
\text { Beta } \\
\text { (Std. Err.) }\end{array}$ & $\begin{array}{c}\text { OLS: M3 } \\
\text { Beta } \\
\text { (Std. Err.) }\end{array}$ & $\begin{array}{c}\text { OLS: M4 } \\
\text { Beta } \\
\text { (Std. Err.) }\end{array}$ & $\begin{array}{c}\text { OLS: M5 } \\
\text { Beta } \\
\text { (Std. Err.) }\end{array}$ \\
\hline Intercept & $\begin{array}{r}4.293^{* *} \\
(0.342)\end{array}$ & $\begin{array}{r}4.580^{* *} \\
(0.275)\end{array}$ & $\begin{array}{r}6.007^{* *} \\
(0.276)\end{array}$ & $\begin{array}{r}6.277^{* *} \\
(0.277)\end{array}$ & $\begin{array}{r}5.259 * * \\
(0.272)\end{array}$ \\
\hline \multicolumn{6}{|l|}{ Socioeconomics } \\
\hline Mean Age & $\begin{array}{c}-0.147^{*} \\
(0.072)\end{array}$ & $\begin{array}{r}-0.172 * * \\
(0.058)\end{array}$ & $\begin{array}{r}-0.180 * * \\
(0.056)\end{array}$ & $\begin{array}{r}-0.187^{* *} \\
(0.056)\end{array}$ & $\begin{array}{r}-0.170 * * \\
(0.057)\end{array}$ \\
\hline Self Employed & $\begin{array}{r}0.047 \\
(0.024)\end{array}$ & $\begin{array}{r}0.054^{* *} \\
(0.020)\end{array}$ & $\begin{array}{r}0.070^{* *} \\
(0.019)\end{array}$ & $\begin{array}{r}0.085^{* *} \\
(0.019)\end{array}$ & $\begin{array}{r}0.081^{* *} \\
(0.019)\end{array}$ \\
\hline University Degree & $\begin{array}{r}-0.094^{* *} \\
(0.019)\end{array}$ & $\begin{array}{r}-0.087 * * \\
(0.015)\end{array}$ & $\begin{array}{r}-0.101 * * \\
(0.015)\end{array}$ & $\begin{array}{r}-0.116^{* *} \\
(0.015)\end{array}$ & $\begin{array}{r}-0.126^{* *} \\
(0.015)\end{array}$ \\
\hline \multicolumn{6}{|l|}{ Travel } \\
\hline One Car & $\begin{array}{r}-0.062 \\
(0.039)\end{array}$ & $\begin{array}{r}-0.125 * * \\
(0.032)\end{array}$ & $\begin{array}{r}-0.134 * * \\
(0.031)\end{array}$ & $\begin{array}{r}-0.122 * * \\
(0.030)\end{array}$ & $\begin{array}{r}-0.115^{* *} \\
(0.031)\end{array}$ \\
\hline Drive Commute & $\begin{array}{r}-0.164^{* *} \\
(0.039)\end{array}$ & $\begin{array}{r}-0.110 * * \\
(0.032)\end{array}$ & $\begin{array}{r}-0.118^{* *} \\
(0.031)\end{array}$ & $\begin{array}{r}-0.118^{* *} \\
(0.030)\end{array}$ & $\begin{array}{r}-0.112^{* *} \\
(0.031)\end{array}$ \\
\hline Over 30km Commute & $\begin{array}{r}0.189 * * \\
(0.008)\end{array}$ & $\begin{array}{r}0.163^{* *} \\
(0.006)\end{array}$ & $\begin{array}{r}0.147^{* *} \\
(0.006)\end{array}$ & $\begin{array}{r}0.152^{* *} \\
(0.006)\end{array}$ & $\begin{array}{r}0.167 * * \\
(0.006)\end{array}$ \\
\hline \multicolumn{6}{|l|}{ Household } \\
\hline Population Density & $\begin{array}{r}-0.048^{* *} \\
(0.006)\end{array}$ & $\begin{array}{r}-0.040 * * \\
(0.005)\end{array}$ & $\begin{array}{r}-0.046 * * \\
(0.004)\end{array}$ & $\begin{array}{r}-0.048^{* *} \\
(0.004)\end{array}$ & $\begin{array}{r}-0.047^{* *} \\
(0.004)\end{array}$ \\
\hline Mean Residents & $\begin{array}{r}0.928 * * \\
(0.082)\end{array}$ & $\begin{array}{r}0.698 * * \\
(0.067)\end{array}$ & $\begin{array}{r}0.592 * * \\
(0.065)\end{array}$ & $\begin{array}{r}0.599 * * \\
(0.065)\end{array}$ & $\begin{array}{r}0.617 * * \\
(0.066)\end{array}$ \\
\hline Rent Social & $\begin{array}{r}0.028^{* *} \\
(0.006)\end{array}$ & $\begin{array}{r}0.017^{* *} \\
(0.005)\end{array}$ & $\begin{array}{r}0.008 \\
(0.005)\end{array}$ & $\begin{array}{r}0.008 \\
(0.005)\end{array}$ & $\begin{array}{r}0.008 \\
(0.005)\end{array}$ \\
\hline Flats & $\begin{array}{r}0.008 \\
(0.005)\end{array}$ & $\begin{array}{l}0.009^{*} \\
(0.004)\end{array}$ & $\begin{array}{r}0.010^{* *} \\
(0.004)\end{array}$ & $\begin{array}{r}0.012^{* *} \\
(0.004)\end{array}$ & $\begin{array}{r}0.012 * * \\
(0.004)\end{array}$ \\
\hline \multicolumn{6}{|c|}{ Nearness to the Republic of Ireland } \\
\hline $5 \mathrm{~km}$ Buffer & & $\begin{array}{r}0.241^{* *} \\
(0.013)\end{array}$ & & & \\
\hline 10km Buffer & & $\begin{array}{r}0.232^{* *} \\
(0.019)\end{array}$ & & & \\
\hline $15 \mathrm{~km}$ Buffer & & $\begin{array}{r}0.231^{* *} \\
(0.022)\end{array}$ & & & \\
\hline 20km Buffer & & $\begin{array}{r}0.163 * * \\
(0.021)\end{array}$ & & & \\
\hline Distance to Crossing & & & $\begin{array}{r}-0.107 * * \\
(0.004)\end{array}$ & & \\
\hline Network Distance to Fuel & & & & $\begin{array}{r}-0.128^{* *} \\
(0.005)\end{array}$ & \\
\hline Network Time to Fuel & & & & & $\begin{array}{r}-0.135^{* *} \\
(0.006)\end{array}$ \\
\hline \multicolumn{6}{|l|}{ Goodness of Fit } \\
\hline$R^{2}$ & 0.784 & 0.862 & 0.869 & 0.871 & 0.867 \\
\hline Log Likelihood & 448.701 & 648.562 & 670.487 & 678.105 & 663.179 \\
\hline AIC & -875.403 & -1267.12 & -1316.97 & -1332.21 & -1302.36 \\
\hline \multicolumn{6}{|l|}{ Spatial Diagnostics } \\
\hline Robust LM (lag) & $17.355^{* *}$ & $9.132 * *$ & $5.673 * *$ & $5.549 * *$ & $5.718^{*}$ \\
\hline Robust LM (error) & $761.4268 * *$ & $501.963 * *$ & $524.648 * *$ & $514.523 * *$ & $496.497 * *$ \\
\hline
\end{tabular}


$*_{\text {- }}$-value $<.05 ;{ }^{* *}-\mathrm{p}$-value $<.01$

The results of the SDEM are reported in Table 3. Comparing the Akaike Information Criterion (AIC) across OLS: Model 4 and the SDEM indicates that the extension of the model provides a significant improvement in the model's ability to account for variance in the rate of private diesel car ownership. In terms of the socioeconomic characteristics included in the model, the mean age of the population holds a significant direct effect (Beta: -0.154), implying that younger populations are linked with diesel car ownership. The proportion of the population that is classified as self-employed also displays a significant direct effect (Beta: 0.068). The variable measuring the proportion of the population that holds a university degree has a significant indirect effect (Beta: -0.099 ), indicating that the presence of educated residents in the vicinity is associated with reductions in diesel car ownership.

Table 3: Results of the Spatial Durbin Error Model with the proportion of the private car fleet that is fuelled by diesel as the dependent variable $(n=890)$

\begin{tabular}{|c|c|c|c|}
\hline & $\begin{array}{c}\text { Direct } \\
\text { Beta } \\
\text { (Std. Err.) }\end{array}$ & $\begin{array}{c}\text { Indirect } \\
\text { Beta } \\
\text { (Std. Err.) }\end{array}$ & $\begin{array}{c}\text { Total } \\
\text { Beta } \\
\text { (Std. Err.) }\end{array}$ \\
\hline \multicolumn{4}{|l|}{ Socioeconomics } \\
\hline Mean Age & $\begin{array}{r}-0.154^{* *} \\
(0.042)\end{array}$ & $\begin{array}{r}-0.071 \\
(0.108)\end{array}$ & $\begin{array}{l}-0.225 \\
(0.130)\end{array}$ \\
\hline Self Employed & $\begin{array}{r}0.068^{* *} \\
(0.014)\end{array}$ & $\begin{array}{r}0.002 \\
(0.039)\end{array}$ & $\begin{array}{r}0.070 \\
(0.047)\end{array}$ \\
\hline University Degree & $\begin{array}{r}0.004 \\
(0.013)\end{array}$ & $\begin{array}{r}-0.099 * * \\
(0.031)\end{array}$ & $\begin{array}{r}-0.095 * * \\
(0.035)\end{array}$ \\
\hline \multicolumn{4}{|l|}{ Travel } \\
\hline One Car & $\begin{array}{r}-0.118^{* *} \\
(0.024)\end{array}$ & $\begin{array}{r}-0.067 \\
(0.059)\end{array}$ & $\begin{array}{r}-0.185 * * \\
(0.070)\end{array}$ \\
\hline Drive Commute & $\begin{array}{r}-0.112 * * \\
(0.028)\end{array}$ & $\begin{array}{r}-0.049 \\
(0.064)\end{array}$ & $\begin{array}{r}-0.161^{* *} \\
(0.073)\end{array}$ \\
\hline Over 30km Commute & $\begin{array}{r}0.059 * * \\
(0.008)\end{array}$ & $\begin{array}{r}0.087^{* *} \\
(0.014)\end{array}$ & $\begin{array}{r}0.146 * * \\
(0.015)\end{array}$ \\
\hline \multicolumn{4}{|l|}{ Household } \\
\hline Population Density & $\begin{array}{r}-0.022^{* *} \\
(0.003)\end{array}$ & $\begin{array}{r}-0.028^{* *} \\
(0.009)\end{array}$ & $\begin{array}{r}-0.050 * * \\
(0.010)\end{array}$ \\
\hline Mean Residents & $\begin{array}{r}0.418^{* *} \\
(0.052)\end{array}$ & $\begin{array}{r}0.202 \\
(0.127)\end{array}$ & $\begin{array}{r}0.620^{* *} \\
(0.152)\end{array}$ \\
\hline Rent Social & $\begin{array}{l}0.008^{*} \\
(0.003)\end{array}$ & $\begin{array}{r}0.005 \\
(0.009)\end{array}$ & $\begin{array}{r}0.013 \\
(0.011)\end{array}$ \\
\hline Flats & $\begin{array}{l}0.007^{*} \\
(0.003)\end{array}$ & $\begin{array}{r}0.006 \\
(0.007)\end{array}$ & $\begin{array}{r}0.012 \\
(0.008)\end{array}$ \\
\hline \multicolumn{4}{|c|}{ Nearness to the Republic of Ireland } \\
\hline Network Distance to Fuel & $\begin{array}{r}-0.011 \\
(0.021)\end{array}$ & $\begin{array}{r}-0.127^{* *} \\
(0.025)\end{array}$ & $\begin{array}{r}-0.139 * * \\
(0.014)\end{array}$ \\
\hline \multicolumn{4}{|c|}{ Spatial Interaction Effect } \\
\hline$\lambda$ & $\begin{array}{r}0.781^{* *} \\
(0.024)\end{array}$ & & \\
\hline \multicolumn{4}{|l|}{ Goodness of Fit } \\
\hline Log Likelihood & 1053.36 & & \\
\hline AIC & -2056.7 & & \\
\hline
\end{tabular}

$*_{\text {- }}$-value $<.05 ;{ }^{* *}$ - p-value $<.01$ 
The travel characteristics included in the model begin with the proportion of one car households which holds a significant direct effect (Beta: -0.118 ), implying that areas that have high levels of single car households tend to have lower rates of diesel cars. The proportion of the population that drives a car to work displays a significant negative direct effect (Beta: -0.112). On the surface, this result seems counterintuitive, as car commuters are generally thought to favour the increased fuel economy that diesel cars offer. However, this issue is likely captured by the variable measuring the proportion of car commuters that travel over 30 kilometres to work, which has the expected significant positive direct (Beta: 0.059) and indirect (Beta: 0.087) effects. Thus, the negative coefficient for car commuters could be a factor of short distance car commuters that are associated with petrol cars.

The variable measuring population density holds a significant direct (Beta: -0.022 ) and indirect (Beta: -0.028 ) effect in the model. These results imply that higher density within and in the vicinity of areas tends to coincide with lower rates of diesel car ownership. Having controlled for the relatively high degree of rurality in the border region, the effect of nearness to the border can be more effectively estimated, with the network distance to the nearest fuel station in the Republic having a significant indirect (Beta: -0.127) and total effect (Beta: -0.139). The mean number of residents per household displays a significant direct effect (Beta: 0.418 ), with this finding potentially linked to larger households being more inclined to own larger cars which are more likely to be fuelled by diesel. The variables measuring both the proportion of households that are rented socially (e.g. from a local authority) and are classified as flats hold significant positive direct effects, through the size of their coefficients indicates that they are of secondary importance.

\section{Conclusions}

Spatial differences across jurisdictions in the cost of goods are known to distort the sales of those goods in the vicinity of the relevant borders. This paper investigates such distortions with respect to diesel fuel price differentials that have existed for the past 15 years between the Republic of Ireland and Northern Ireland. However, instead of investigating patterns in the sale of the good itself (i.e. diesel fuel), the analysis uses novel spatial statistics to determine whether there has been a knock-on impact on the composition of the private car fleet.

Due to the friction of distance (i.e. the cost of driving across the border to refuel), the hypothesis is that the availability of cheaper diesel is having the most effect in locations nearest to the Republic as opposed to locations far removed from it. The spatial analysis provides evidence supporting this hypothesis, by demonstrating that network distance to fuel stations in the Republic is associated with increased rates of private diesel car ownership. This association remains after controlling for the effect of the socioeconomic, travel, and household characteristics included in the model. Making use of the parameters of OLS Model 3, it is possible to estimate the size of the effect on the fleet. This simulation is achieved by setting the parameters of the dummy variables which denote buffer categories from the border to zero and then using the remaining model parameters to calculate diesel car share for each SOA. The results of this simulation indicate that there would be 33,100 fewer private diesel cars in Northern Ireland if the availability of cheaper fuel in the Republic was not present, which equates to $4.0 \%$ of the car fleet. This estimate is likely conservative, as it is debatable whether the dummy variables fully capture the effect of fuel tourism and smuggling.

A number of policy-relevant conclusions can be drawn from this case study. First, fiscal measures that are enacted in one country may extend their reach into another. Transitioning national car fleets away from diesel fuel and towards hybrid and pure battery electric vehicles is a topical issue for many countries around the globe. The results of the analysis indicate that where neighbouring jurisdictions have differences in fuel taxation regimes, this may have implications for the ability of a government to manage its car stock and could dampen transition strategies. While the case study presented here examines the border between Northern Ireland and the Republic of Ireland, there are likely other examples of where similar issues will be present across neighbouring jurisdictions. 
In addition, there is fresh recognition in the European Union that the historically favourable treatment of diesel with respect to fuel tax has hampered efforts to tackle air quality targets. The findings of the analysis imply that cooperation between neighbouring European Union countries is necessary in the setting of fiscal measures to control the use of diesel cars so that a shift away from diesel can be achieved. With the UK expected to withdraw from the European Union in 2019 (i.e. Brexit), this may hamper such coordination along the Irish border. It is challenging to predict the specific consequences of Brexit, as the details of the withdraw are currently vague. It is plausible that Brexit may restrict fuel tourism in both the short term, through increasing the friction of distance due to the introduction of border checks, and in the medium term, if the economic performance of the UK is dampened leading to diminished fuel demand.

The second implication is primarily a methodological point, but one with relevance to policy makers and researchers alike. As this study has demonstrated, the car stock of one country is not a closed system and can be subject to exogenous factors (e.g. the price of fuel available in neighbouring countries). This means that vehicle stock and energy demand models which do not take account of this potential coupling between countries are likely to produce biased forecasts and may have consequences for the accuracy of energy and emissions accounting. Indeed, with the emissions generated from transport fuel use generally being assigned on a sales rather than a consumption based approach, such a reporting system can have substantial consequences for carbon accounting across Ireland (Dineen et al. 2014).

\section{Acknowledgements}

This work has been undertaken as part of the MOT project (EP/K000438/1), funded by the UK Engineering and Physical Sciences Research Council under the Research Councils UK Energy Programme. Additional support was provided by the ClimateXChange centre in Scotland. The work was made possible due to data provided by the Department for Transport.

\section{References}

Adjemian, M. K., Cynthia Lin, C.-Y., \& Williams, J. (2010). Estimating spatial interdependence in automobile type choice with survey data. Transportation Research Part A: Policy and Practice, 44(9), 661-675. https://doi.org/10.1016/j.tra.2010.06.001

Anselin, L. (1995). Local Indicators of Spatial Association-LISA. Geographical Analysis, 27(2), 93115. https://doi.org/10.1111/i.1538-4632.1995.tb00338.x

Anselin, L., Bera, A. K., Florax, R., \& Yoon, M. J. (1996). Simple diagnostic tests for spatial dependence. Regional Science and Urban Economics, 26(1), 1996, 77-104. https://doi.org/10.1016/0166-0462(95)02111-6

Association des Constructeurs Européens d'Automobiles. (2017). Share of diesel in new passenger vehicles. Available at: http://www.acea.be/statistics/article/Share-of-diesel-in-new-passenger-cars, Accessed 26 July 2017.

Automobile Association. (2017). UK and Overviews Petrol and Diesel Prices. Available at: http://www.theaa.com/driving-advice/driving-costs/fuel-prices. Accessed 26 July 2017.

Carslaw, D. C., Beevers, S. D., Tate, J. E., Westmoreland, E. J., \& Williams, M. L. (2011). Recent evidence concerning higher NOx emissions from passenger cars and light duty vehicles. Atmospheric Environment, 45(39), 7053-7063. https://doi.org/10.1016/j.atmosenv.2011.09.063 
Chatterton, T., Barnes, J., Wilson, R.E., Anable, J., \& Cairns, S. (2015) Use of a novel dataset to explore spatial and social variations in car type, size, usage and emissions. Transportation Research D: Transport and Environment, 39, pp.151-164. https://doi.org/ 10.1016/j.trd.2015.06.003

Clark, S. D. (2007). Estimating local car ownership models. Journal of Transport Geography, 15(3), 184-197. https://doi.org/10.1016/i.jtrangeo.2006.02.014

Clark, S., \& Finley, A. O. (2010). Spatial Modelling of Car Ownership Data: A Case Study from the United Kingdom. Applied Spatial Analysis and Policy, 3(1), 45-65. https://doi.org/10.1007/s12061$\underline{009-9030-z}$

Clark, S. D., \& Rey, S. (2017). Temporal dynamics in local vehicle ownership for Great Britain. Journal of Transport Geography, 62, 30-37. https://doi.org/10.1016/i.jtrangeo.2017.05.007

Banfi, S., Filippini, M., \& Hunt, L. C. (2005). Fuel tourism in border regions: The case of Switzerland. Energy Economics, 27(5), 689-707. https://doi.org/10.1016/j.eneco.2005.04.006

Bivand, R., Anselin, L., Berke, O., Bernat, A., Carvalho, M., Chun, Y., Dormann, C.F., Dray, S., Halbersma, R. \& Lewin-Koh, N. (2011). SPDEP: Spatial dependence: weighting schemes, statistics and models. Available at: https://cran.r-project.org/web/packages/spdep/index.html. Accessed 26 July 2017.

Bonilla, D. (2009). Fuel demand on UK roads and dieselisation of fuel economy. Energy Policy, 37(10), 3769-3778. https://doi.org/10.1016/i.enpol.2009.07.016

Brand, C. (2016). Beyond "Dieselgate": Implications of unaccounted and future air pollutant emissions and energy use for cars in the United Kingdom. Energy Policy, 97, 1-12.

https://doi.org/10.1016/i.enpol.2016.06.036

Brand, C., Anable, J., \& Tran, M. (2013). Accelerating the transformation to a low carbon passenger transport system: The role of car purchase taxes, feebates, road taxes and scrappage incentives in the UK. Transportation Research Part A: Policy and Practice, 49, 132-148.

https://doi.org/10.1016/j.tra.2013.01.010

Cairns, S., Anable, J., Chatterton, T., Wilson, R.E. \& Morton, C. (2017) MOToring along: The lives of cars seen through licensing and test data. Report for the RAC Foundation, November 2017.

Department for Transport. (2016). Vehicle licensing statistics.

https://www.gov.uk/government/collections/vehicles-statistics. Accessed 26 July 2017.

Dimatulac, T., \& Maoh, H. (2017). The spatial distribution of hybrid electric vehicles in a sprawled mid-size Canadian city: Evidence from Windsor, Canada. Journal of Transport Geography, 60, 59-67. https://doi.org/10.1016/i.jtrangeo.2017.02.010

Dineen, D., Howley, M., \& Holland, M. (2014) Energy in Transport. Report for the Sustainable Energy Authority in Ireland. Available at: https://www.seai.ie/resources/publications/Energy-in-Transport2014-report.pdf. Accessed 15 May 2018.

Elhorst, J. P. (2014). Spatial Econometrics: From Cross-Sectional Data to Spatial Panels. New York: Springer.

Harris, R., Sleight, P., Webber, R., \& (2005). Geodemographics, GIS and neighbourhood targeting. Wiley, West Sussex, England; Hoboken, N.J. 
House of Commons. (2012). Fuel laundering and smuggling in Northern Ireland. Available at: http://www.parliament.uk/business/committees/committees-a-z/commons-select/northernireland-affairs-committee/inquiries/parliament-2010/fuel-laundering-and-smuggling/. Accessed 26 July 2017.

Kennedy, S., Lyons, S., Morgenroth, E., \& Walsh, K. (2017). Assessing the level of cross-border fuel tourism. Irish Journal of Social, Economic, and Environmental Sustainability, 1(2), 4-22.

Kågeson, P. (2013). Dieselization in Sweden. Energy Policy, 54, 42-46.

https://doi.org/10.1016/j.enpol.2012.09.006

Lansley, G. (2016). Cars and socio-economics: understanding neighbourhood variations in car characteristics from administrative data. Regional Studies, Regional Science, 3(1), 264-285. https://doi.org/10.1080/21681376.2016.1177466

Leal, A., López-Laborda, J., \& Rodrigo, F. (2009). Prices, taxes and automotive fuel cross-border shopping. Energy Economics, 31(2), 225-234. https://doi.org/10.1016/j.eneco.2008.09.007

Leal, A., López-Laborda, J., \& Rodrigo, F. (2010). Cross-Border Shopping: A Survey. International Advances in Economic Research, 16(2), 135-148. https://doi.org/10.1007/s11294-010-9258-z

LeSage, J., \& Pace, R. K. (2009). Introduction to Spatial Econometrics. Boca Raton: Chapman and Hall/CRC.

Liu, X., Roberts, M. C., \& Sioshansi, R. (2017). Spatial effects on hybrid electric vehicle adoption. Transportation Research Part D: Transport and Environment, 52, Part A, 85-97. https://doi.org/10.1016/i.trd.2017.02.014

Lovelace, R., \& Ellison, R. (Under Review). "Stplanr: A Package for Transport Planning." Available at: https://github.com/ropensci/stplanr. Accessed: 10 April 2018.

Mannberg, A., Jansson, J., Pettersson, T., Brännlund, R., \& Lindgren, U. (2014). Do tax incentives affect households' adoption of 'green' cars? A panel study of the Stockholm congestion tax. Energy Policy, 74, 286-299. https://doi.org/10.1016/j.enpol.2014.08.029

Mazzi, E. A., \& Dowlatabadi, H. (2007). Air Quality Impacts of Climate Mitigation: UK Policy and Passenger Vehicle Choice. Environmental Science \& Technology, 41(2), 387-392.

https://doi.org/10.1021/es060517w

Moody, A., \& Tate, J. (2017). In Service CO2 and NOX Emissions of Euro 6/VI Cars, Light- and Heavydutygoods Vehicles in Real London driving: Taking the Road into the Laboratory. Journal of Earth Sciences and Geotechnical Engineering, 7(1), 51-62. Retrieved

from http://www.scienpress.com/journal focus.asp?main id=59\&Sub id=IV\&Issue=94463

Moran, P. A. P. (1948). The Interpretation of Statistical Maps. Journal of the Royal Statistical Society. Series B (Methodological), 10(2), 243-251.

Morton, C., Lovelace, R., \& Anable, J. (2017). Exploring the effect of local transport policies on the adoption of low emission vehicles: Evidence from the London Congestion Charge and Hybrid Electric Vehicles. Transport Policy, 60, 34-46. https://doi.org/10.1016/j.tranpol.2017.08.007 
National Roads Authority, (2013). The Impact of Fuel Prices on Fuel Consumption and Traffic in Ireland. Available at: http://www.tii.ie/tii-library/strategic-planning/transport-research-andinformation-notes(trins)/The-Impact-of-Fuel-Prices-on-Fuel-Consumption-and-Traffic-in-Ireland-.pdf. Accessed 15 May 2018.

Northern Ireland Statistics and Research Agency. (2011). Population census of Northern Ireland. https://www.nisra.gov.uk/statistics/2011-census/results. Accessed 26 July 2017.

Ozaki, R., \& Sevastyanova, K. (2011). Going hybrid: An analysis of consumer purchase motivations. Energy Policy, 39(5), 2217-2227. https://doi.org/10.1016/j.enpol.2010.04.024 Rietveld, P., and van Woudenberg, S. (2005). Why fuel prices differ. Energy Economics, 27(1), 79-92. https://doi.org/10.1016/i.eneco.2004.10.002

R Core Team. R: A Language and Environment for Statistical Computing. Vienna, Austria, 2017. https://www.R-project.org/.

Rietveld, P., Bruinsma, F. R., \& van Vuuren, D. J. (2001). Spatial graduation of fuel taxes; consequences for cross-border and domestic fuelling. Transportation Research Part A: Policy and Practice, 35(5), 433-457. https://doi.org/10.1016/S0965-8564(00)00002-1

Romero-Jordán, D., García-Inés, M. J., \& García, S. Á. (2013). The impact of fuel tourism on retailers' diesel price in Spanish neighbouring regions. Applied Economics, 45(4), 407-413.

https://doi.org/10.1080/00036846.2011.605757

Royal College of Physicians. (2016). Every breath we take: The lifelong impact of air pollution. Available at: https://www.rcplondon.ac.uk/projects/outputs/every-breath-we-take-lifelong-impactair-pollution. Accessed 26 July 2017.

Schipper, L., Marie-Lilliu, C., \& Fulton, L. (2002). Diesels in Europe: Analysis of Characteristics, Usage Patterns, Energy Savings and $\mathrm{CO}_{2}$ Emission Implications. Journal of Transport Economics and Policy, 36(2), 305-340. Retrieved from http://www.jstor.org/stable/20053905

Schipper, L., \& Fulton, L. (2009). Disappointed by Diesel? Transportation Research Record: Journal of the Transportation Research Board, 2139, 1-10. https://doi.org/10.3141/2139-01

Schipper, L., \& Fulton, L. (2013). Dazzled by diesel? The impact on carbon dioxide emissions of the shift to diesels in Europe through 2009. Energy Policy, 54, 3-10.

https://doi.org/10.1016/i.enpol.2012.11.013

Transport and Environment, (2011). Fuelling oil demand: What happened to fuel taxation in Europe? Available at: https://www.transportenvironment.org/publications/report-fuelling-oil-demand-whathappened-fuel-taxation-europe. Accessed 7 April 2018.

Tovar, M. A. (2011). An integral evaluation of dieselisation policies for households' cars. Energy Policy, 39(9), 5228-5242. https://doi.org/10.1016/j.enpol.2011.05.041

Whitehead, J., Franklin, J. P., \& Washington, S. (2014). The impact of a congestion pricing exemption on the demand for new energy efficient vehicles in Stockholm. Transportation Research Part A: Policy and Practice, 70(Supplement C), 24-40. https://doi.org/10.1016/i.tra.2014.09.013

Zachariadis, T. (2013). Gasoline, diesel and climate policy implications-Insights from the recent evolution of new car sales in Germany. Energy Policy, 54, 23-32.

https://doi.org/10.1016/i.enpol.2011.11.075 